\title{
Assessment of Heavy Metals on Fortified Municipal Solid Waste Compost Treated Soils (Typic Ustropet) in Okra (Abelmoschus esculentus (L.) Moench) - Onion (Allium cepa L.) Cropping Sequence
}

\author{
V.S. Reddy Kiran Kalyan ${ }^{1 *}$, G. Sudha Narayani ${ }^{1}$, A. Vijayaprabhakar ${ }^{2}$ \\ and Ch. Bhargavarami Reddy ${ }^{1}$ \\ ${ }^{1}$ Department of Soil Science and Agricultural Chemistry, Tamil Nadu Agricultural University, \\ Coimbatore, Tamilnadu, 641003, India \\ ${ }^{2}$ Department of Agronomy, Tamil Nadu Agricultural University, Coimbatore, \\ Tamilnadu, 641003, India \\ *Corresponding author:
}

\begin{tabular}{|c|c|}
\hline & A B S T RA C T \\
\hline $\begin{array}{l}\text { Ke y w o r d s } \\
\text { Organic manure, } \\
\text { Farm yard manure, } \\
\text { Municipal solid } \\
\text { waste compost, } \\
\text { Heavy metals. }\end{array}$ & $\begin{array}{l}\text { From the experimental results emanated from first crop of okra, among the Municipal } \\
\text { Solid Waste Compost (MSWC) treatments application of } 100 \% \text { Rec. NK + FMSWC with } \\
\text { poultry manure } 10 \%(9: 1) \text { at } 5 \mathrm{t} \mathrm{ha}^{-1} \text { along with phosphorus }\left(\mathrm{M}_{4} \mathrm{P}_{1}\right) \text { recorded lowest Pb, Ni } \\
\text { and Cd contents at harvest stage in soil which was on par with the treatment, } 100 \% \text { Rec. } \\
\text { NK + FMSWC with SSP at } 5 \mathrm{t} \mathrm{ha}^{-1} \text { along with phosphorus }\left(\mathrm{M}_{7} \mathrm{P}_{1}\right) \text { which was significantly } \\
\text { lower than that of other treatments with FMSWC at higher doses. Onion crop was raised as } \\
\text { succeeding crop to study the residual effect of municipal solid waste compost. From the }\end{array}$ \\
\hline Article Info & $\begin{array}{l}\text { experimental results, the application of } 100 \% \text { Rec. NK + FMSWC with poultry manure } \\
10 \%(9: 1) \text { at } 5 \mathrm{t} \mathrm{ha}^{-1} \text { with phosphorus }\left(60 \mathrm{~kg} \mathrm{ha}^{-1}\right)\left(\mathrm{M}_{4} \mathrm{P}_{1}\right) \text { registered lowest heavy metal } \mathrm{Pb} \text {, }\end{array}$ \\
\hline $\begin{array}{l}\text { Accepted: } \\
18 \text { January } 2017 \\
\text { Available Online: } \\
10 \text { February } 2017\end{array}$ & $\begin{array}{l}\mathrm{Ni} \text { and Cd contents in soil which was on par with the treatment, } 100 \% \text { Rec. NK + FMSWC } \\
\text { with SSP at } 5 \mathrm{t} \mathrm{h}^{-1} \text { along with phosphorus }\left(60 \mathrm{~kg} \mathrm{ha}^{-1}\right)\left(\mathrm{M}_{7} \mathrm{P}_{1}\right) \text { as compared to other } \\
\text { treatments with FMSWC higher doses. With regard to heavy metals accumulation in soil, } \\
\text { plant, fruit and bulb samples is below the permissible limits as prescribed by Indian } \\
\text { standards (2013) and World Health Organization }(2007) \text {. }\end{array}$ \\
\hline
\end{tabular}

\section{Introduction}

Application of organic manure is the most widely practiced technology for nutrient replenishment in soil. Before 1950, organic manure was the only source of plant nutrients and owing to high animal population, farm yard manure was the most common organic manure. During those days, cattle's account for 90 percent of total manure production. The proportion of cattle manure available for crop production decreased from 70 percent in the early 1970s to 30 percent in the early 1990s. Although FYM is commonly used organic manure, it is not adequately available in the recent days due to decrease in cattle population. Hence, there is a strong need to identify suitable organic source alternative to FYM. Increasing population levels, booming economy, rapid urbanization and rise in community living standards have greatly accelerated the municipal solid waste 
generation rate in developing countries (Minghua et al., 2009). MSWC increased the aggregate stability of soil through the formation of cationic bridges thereby, improving the soil structure (Hernando et al., 1989). Municipal solid waste also contains considerable concentrations of heavy metals such as $\mathrm{As}, \mathrm{Pb}$, $\mathrm{Ni}, \mathrm{Cd}$ and $\mathrm{Cr}$. With the light of above, the experiment was conducted with10 different main plot treatments comprising three levels of fortified MSWC (5, 7.5 and $\left.10 \mathrm{tha}^{-1}\right)$ and two subplot phosphorus levels $(0,100 \%)$ and along with control.

\section{Materials and Methods}

Municipal solid waste compost collected from the Municipal solid waste compost plant located at Vellalore, Coimbatore district which is being operated by United Phosphorus Ltd, Mumbai in collaboration with Coimbatore Corporation was fortified with poultry manure at $10 \%(9: 1)$ and with single super phosphate at $50 \mathrm{~kg}$ per tonne. The fortified compost was heaped under aerobic condition for twenty one days and analyzed for its physico-chemical and chemical properties. The experimental field was ploughed thoroughly and levelled properly. Ridges and furrows were formed at $45 \mathrm{~cm}$ apart. Irrigation channels were formed separately for each row, so that manures and fertilizers will not be translocated from one plot to another. The plot size was $4 \times 3 \mathrm{~m}(12$ $\mathrm{m}^{2}$ ). The experiment was laid out in spilt plot design replicated thrice with the following main plot treatments: $\mathrm{M}_{0}-$ Control, $\mathrm{M}_{1}-100 \%$ Rec. NK, $\mathrm{M}_{2}-100 \%$ Rec. NK + FYM $25 \mathrm{t} \mathrm{ha}^{-1}, \mathrm{M}_{3}$ - $100 \%$ Rec. NK + Unfortified MSWC at $5 \mathrm{t}$ $\mathrm{ha}^{-1}, \mathrm{M}_{4}-100 \%$ Rec. NK + PM Fortified MSWC at $5 \mathrm{t} \mathrm{ha}{ }^{-1}, \mathrm{M}_{5}-100 \%$ Rec. NK + PM Fortified MSWC at $7.5 \mathrm{t} \mathrm{ha}^{-1}, \mathrm{M}_{6}-100 \%$ Rec. $\mathrm{NK}+\mathrm{PM}$ Fortified MSWC at $10 \mathrm{t} \mathrm{ha}^{-1}, \mathrm{M}_{7}-$ $100 \%$ Rec. NK + SSP Fortified MSWC at $5 \mathrm{t}$ ha $^{-1}, \mathrm{M}_{8}-100 \%$ Rec. NK + SSP Fortified MSWC at $7.5 \mathrm{t} \mathrm{ha}^{-1}$ and $\mathrm{M}_{9}-100 \%$ Rec. NK +
SSP Fortified MSWC at $10 \mathrm{t} \mathrm{ha}^{-1}$. The soil belongs to Irgur series (Typic Ustropet), loamy sand in texture, non-calcareous, slightly alkaline in reaction with low available nitrogen, high available phosphorus and high available potassium. The soil is sufficient in iron $\left(2.91 \mathrm{mg} \mathrm{kg}^{-1}\right)$ and manganese $\left(12.2 \mathrm{mg} \mathrm{kg}^{-}\right.$ $\left.{ }^{1}\right)$, deficient in zinc $\left(0.65 \mathrm{mg} \mathrm{kg}^{-1}\right)$ and copper $\left(0.82 \mathrm{mg} \mathrm{kg}^{-1}\right)$ and with traces of heavy metals. Soil samples were collected at harvest stage of okra crop and vegetative, bulb initiation, bulb development and post harvest stages of onion crop, processed and analyzed for heavy metal concentration by using DTPA extractant method (Lindsay and Norvell, 1978).

\section{Results and Discussion}

From the experimental results, the available lead status of the experimental soil was 3.15 $\mathrm{mg} \mathrm{kg}^{-1}$. At harvest stage, the treatment which received $100 \%$ Rec. NK + FMSWC with poultry manure $10 \%(9: 1)$ at $5 \mathrm{t} \mathrm{ha}^{-1}$ along with phosphorus application (100 $\left.\mathrm{kg} \mathrm{ha}^{-1}\right)\left(\mathrm{M}_{4} \mathrm{P}_{1}\right)$ showed minimum value of available lead status $\left(4.57 \mathrm{mg} \mathrm{kg}^{-1}\right.$ ) which was on par with the treatment, $100 \%$ Rec. NK+ FMSWC with SSP at $5 \mathrm{t} \mathrm{ha}^{-1}$ along with phosphorus application $\left(100 \mathrm{~kg} \mathrm{ha}^{-1}\right)\left(\mathrm{M}_{7} \mathrm{P}_{1}\right)$ with the value of $4.64 \mathrm{mg} \mathrm{kg}^{-1}$, as compared to other treatments with FMSWC at higher doses (Fig. 1). The interaction effect between the main plot and sub plot treatments was not significant. Application of MSWC fortified with poultry manure increased heavy metal concentration in soil but it ranged below the permissible limits. This might be due to the application of MSWC, which had sufficient nickel concentration and made available in the soil (Table 1).

Garcia Gil et al., (2004) noticed that application of MSWC at $80 \mathrm{t} \mathrm{ha}^{-1}$ vermicompost accumulated lead in soil which was below the critical limit (11.6 mg kg-1). Madrid et al., (2007) assessed the effect of MSWC on the 
accumulation of heavy metals in a sandy soil and they identified that application of MSWC at $2.1 \mathrm{~kg} \mathrm{~m}^{-2}$ registered maximum concentration of $\mathrm{Pb}\left(2.5 \mathrm{mg} \mathrm{kg}^{-1}\right)$ in soil with tomato as a test crop. Achiba et al., (2009) proved that application of MSWC at $120 \mathrm{t} \mathrm{ha}^{-1}$ recorded the highest concentration of lead in soil (97.1 mg kg-1) with maize as test crop. Gharib (2014) studied the impacts of urban waste water and leachate on accumulation of iron $(\mathrm{Fe})$, manganese $(\mathrm{Mn})$, zinc $(\mathrm{Zn})$, nickel (Ni) and cadmium in soil when barley (Hordeum vulgare L) was grown as test crop. The results showed that soil irrigated with 300 $\mathrm{ml}$ of waste water increased extractable heavy metals in soil and the concentrations of extractable Fe was 2.27 ppm.

The available nickel status of the experimental soil was $1.03 \mathrm{mg} \mathrm{kg}^{-1}$. At harvest stage, the treatment which received $100 \%$ Rec. NK + FMSWC with poultry manure $10 \%(9: 1)$ at $5 \mathrm{t} \mathrm{ha}^{-1}$ along with phosphorus application $\left(100 \mathrm{~kg} \mathrm{ha}^{-1}\right)\left(\mathrm{M}_{4} \mathrm{P}_{1}\right)$ showed minimum value of available nickel status $\left(3.57 \mathrm{mg} \mathrm{kg}^{-1}\right)$ which was on par with the treatment, $100 \%$ Rec. NK+ FMSWC with SSP at $5 \mathrm{t} \mathrm{ha}^{-1}$ along with phosphorus application $\left(\mathrm{M}_{7} \mathrm{P}_{1}\right)$ with the value of $3.48 \mathrm{mg} \mathrm{kg}^{-1}$. The interaction effect between the main plot and sub plot treatments was not significant. Application of MSWC fortified with poultry manure increased heavy metal concentration in soil but it ranged below the permissible limits.

This is might be due to the application of MSWC, which had sufficient nickel and was made available in the soil. Albaladejo et al., (2009) studied the effect of graded municipal solid waste compost and ungraded MSWC which included plastic bags, cans, pipes and e-waste on soil properties and they examined that application of ungraded MSWC at $25 \mathrm{~kg}$ $\mathrm{m}^{-2}$ recorded maximum concentration of nickel (3.1 $\mathrm{mg} \mathrm{kg}^{-1}$ ) (Table 1).
Shulan Zhao et al., (2012) assessed the effect of different particle size fractions of municipal solid waste compost on physical and chemical properties of soil and they reported that application of MSWC having the particle size $0.8 \quad-0.4 \mathrm{~mm}$ registered maximum nickel concentration of $2.50 \mathrm{mg} \mathrm{kg}^{-1}$. Kiayee (2013) investigated the effect of Municipal Waste Leachate (MWL) on soil chemical properties and accumulation of heavy metals in soil by growing wheat as test crop and proved that application of $300 \mathrm{t} \mathrm{ha}^{-1}$ of MWL had registered highest available $\mathrm{Ni}$ in soil (0.38 mg kg-1). Garcia Gil et al., (2004) concluded that application of MSWC at $80 \mathrm{t}$ $\mathrm{ha}^{-1}$ registered maximum accumulation of $\mathrm{Ni}$ (13 $\mathrm{mg} \mathrm{kg}^{-1}$ ) in soil.

The available cadmium status of the experimental soil was $0.78 \mathrm{mg} \mathrm{kg}^{-1}$. At harvest stage, the lowest available $\mathrm{Cd}$ content was recorded in treatment which received $100 \%$ Rec. NK+ FMSWC with poultry manure $10 \%$ (9:1) at $5 \mathrm{t} \mathrm{ha}^{-1}$ along with phosphorus application $\left(100 \mathrm{~kg} \mathrm{ha}^{-1}\right)\left(\mathrm{M}_{4} \mathrm{P}_{1}\right)\left(1.38 \mathrm{mg} \mathrm{kg}^{-1}\right)$ followed by $100 \%$ Rec. NK + FMSWC with SSP at $5 \mathrm{t} \mathrm{ha}^{-1}$ along with phosphorus application $\left(100 \mathrm{~kg} \mathrm{ha}^{-1}\right)\left(\mathrm{M}_{7} \mathrm{P}_{1}\right)$ with the value of $1.32 \mathrm{mg} \mathrm{kg}^{-1}$ as compared to other treatments with FMSWC at higher doses. The interaction effect between the main plot and sub plot treatments was not significant. As the MSWC is a bin of all the heavy metals, a part or fraction may be available in the soil (Table 1).

Albaladejo et al., (2009) showed that application of ungraded MSWC at $25 \mathrm{~kg} \mathrm{~m}^{-2}$ registered maximum cadmium concentration in soil $\left(1.6 \mathrm{mg} \mathrm{kg}^{-1}\right)$. The present results are also in accordance with the findings of Cherifa et al., (2009) who revealed that application of MSWC at $80 \mathrm{Mg} \mathrm{ha}^{-1}$ registered maximum cadmium concentration in soil (2.98 mg kg-1). Achiba et al., (2009) showed that application of MSWC at $120 \mathrm{t}$ $\mathrm{ha}^{-1}$ recorded the maximum concentration of 
Cd (2.8 $\left.\mathrm{mg} \mathrm{kg}^{-1}\right)$ in soil. Kiayee (2013) investigated the effect of Municipal Waste Leachate (MWL) on accumulation of heavy metals in soil by growing wheat as a test crop and proved that application of $300 \mathrm{tha}$ ${ }^{1}$ of MSL had registered highest available $\mathrm{Cd}$ in soil (0.06 ppm).

Available heavy metal concentration in soil was lower at harvest stage of onion compared to that of harvest stage of okra. This may be due to the low mobility of metal ions that forms stable links with organic matter. Also, heavy metal accumulation in soil or plant depends on the type of soil, $\mathrm{pH}$, plant species and rates of compost application.

At harvest stage, application of $100 \%$ Rec. $\mathrm{NK}+\mathrm{MSWC}$ with poultry manure $10 \%(9: 1)$ at $5 \mathrm{t} \mathrm{ha}^{-1}\left(\mathrm{M}_{4} \mathrm{P}_{1}\right)$ recorded lowest available lead $\left(4.48 \mathrm{mg} \mathrm{kg}^{-1}\right)$ which was on par with the treatment, $100 \%$ Rec. NK+ FMSWC with SSP at $5 \mathrm{t} \mathrm{ha}^{-1}\left(\mathrm{M}_{7} \mathrm{P}_{1}\right)$ with the value of 4.31 $\mathrm{mg} \mathrm{kg}^{-1}$ as compared to other treatments with FMSWC at higher doses (Fig. 2). The treatment $\left(\mathrm{M}_{0}\right)$ which received no manure and fertilizer rendered lowest value of $0.65 \mathrm{mg} \mathrm{kg}^{-1}$. The results revealed that the interaction effect between the main plot and sub plot treatments was not significant. Available lead content decreased from vegetative stage to harvest stage due to the continuous uptake of plant. This might be due to application of organic amendments that contribute to metal immobilization through formation of stable complexes with $\mathrm{OH}$ or $\mathrm{COOH}$ groups on the solid surfaces of the organic polymers (Table 2).

Convertini et al., (2004) studied that application of MSWC at $100 \mathrm{~kg} \mathrm{ha}^{-1}$ recorded the highest $\mathrm{Pb}$ content $\left(50 \mathrm{mg} \mathrm{kg}^{-1}\right)$ in soil under two crop rotations viz., tomato- durum wheat and sunflower-durum wheat. Zhang et al., (2006) observed the effect of MSWC on soil nutrient dynamics and crop nutrient uptake by using barley (Hordeum vulgare L.) - wheat (Triticum aestivum L) - canola (Brassica rapa) as cropping sequence and found that application of MSWC at $200 \mathrm{t} \mathrm{ha}^{-1}$ registered highest available lead content of $21.6 \mathrm{mg} \mathrm{kg}^{-1}$ in soil. According to Businelli et al., (2009) metal mobilization is not an immediate process, but it involves various equilibrium that control their adsorption and desorption. This behaviour depends on soil characteristics like $\mathrm{pH}$, organic matter, soil texture and climatic conditions. Topcuoglu (2016) studied the effect of long-term municipal solid waste compost application on soil metal bioavailability by cultivating cucumber crop for three years and found that application of MSWC at100 $\mathrm{t} \mathrm{ha}^{-1}$ increased $\mathrm{Pb}$ concentration in soil from 42.1 to $82.0 \mathrm{mg}$ $\mathrm{kg}^{-1}$.

Application of $100 \%$ Rec. NK + FMSWC with PM $10 \%(9: 1)$ at $5 \mathrm{t} \mathrm{ha}^{-1}\left(\mathrm{M}_{4} \mathrm{P}_{1}\right)$ recorded the lowest available nickel at harvest stages with the values of $1.24 \mathrm{mg} \mathrm{kg}^{-1}$ respectively, which were on par with $100 \%$ Rec. NK + FMSWC with SSP at $5 \mathrm{t} \mathrm{ha}^{-1}\left(\mathrm{M}_{7} \mathrm{P}_{1}\right)\left(1.07 \mathrm{mg} \mathrm{kg}^{-1}\right)$ as compared to other treatments with FMSWC at higher doses (Fig. 2). The lowest values were recorded in control $\left(\mathrm{M}_{0} \mathrm{P}_{0}\right)\left(0.31 \mathrm{mg} \mathrm{kg}^{-1}\right)$. The results revealed that the interaction effect between the main plot and sub plot treatments was not significant (Table 2).

Convertini et al., (2004) investigated that application of MSWC at $100 \mathrm{~kg} \mathrm{ha}^{-1}$ recorded the highest $\mathrm{Ni}$ content of $40 \mathrm{mg} \mathrm{kg}^{-1}$ in soil under sunflower-durum wheat crop rotation. Zhang et al., (2006) observed the effect of MSWC on soil nutrient dynamics and crop nutrient uptake by using barley (Hordeum vulgare L.) - wheat (Triticum aestivum L) canola (Brassica rapa) as cropping sequence and found that application of MSWC at $200 \mathrm{t}$ $\mathrm{ha}^{-1}$ registered highest available nickel content of $16.4 \mathrm{mg} \mathrm{kg}^{-1}$ in soil. The present findings are in line with Topcuoglu (2016) who 
studied the effect of long-term municipal solid waste compost applications on heavy metal availability by using cucumber as a test crop for three consecutive years and found that application of MSWC at $100 \mathrm{t} \mathrm{ha}^{-1}$ increased $\mathrm{Ni}$ concentrations from 15.9 to 30.0 $\mathrm{mg} \mathrm{kg}^{-1}$ in soil.

At harvest stage, the lowest content of available cadmium was recorded in the treatment with application of $100 \%$ Rec. NK + FMSWC with poultry manure $10 \%$ (9:1) at $10 \mathrm{t} \mathrm{ha}^{-1}\left(\mathrm{M}_{4} \mathrm{P}_{1}\right)\left(0.75 \mathrm{mg} \mathrm{kg}^{-1}\right)$ as compared to other treatments with FMSWC at higher doses. The lowest value was recorded in control $\left(\mathrm{M}_{0} \mathrm{P}_{0}\right)\left(0.12 \mathrm{mg} \mathrm{kg}^{-1}\right)$ (Fig. 2). The interaction effect between the main plot and sub plot treatments was not significant. This might be due to alkaline $\mathrm{pH}$ of the soil that contributes to a decrease of heavy metal mobility by the formation of precipitates, by increasing the number of adsorption sites and decreasing the competition of $\mathrm{H}^{+}$for adsorption and thereby increasing the metal stability with humic substances (Pigozzo et al., 2006). Similar findings were reported by Convertini et al., (2004) who observed that application of MSWC at $100 \mathrm{~kg} \mathrm{ha}^{-1}$ recorded the highest $\mathrm{Cd}$ content of $5.5 \mathrm{mg} \mathrm{kg}^{-1}$ in soil under sunflower - durum wheat grown as crop rotation (Table 2 ).

Table.1 Effect of fortified municipal solid waste compost on available heavy metal content $\left(\mathrm{mg} \mathrm{kg}^{-1}\right)$ in soil at harvest stages of okra

\begin{tabular}{|c|c|c|c|c|c|c|c|c|c|}
\hline \multirow{2}{*}{$\begin{array}{l}\text { Treatm } \\
\text { ents }\end{array}$} & \multicolumn{3}{|c|}{$\mathbf{P b}$} & \multicolumn{3}{|c|}{$\mathbf{N i}$} & \multicolumn{3}{|c|}{ Cd } \\
\hline & $\mathbf{P}_{\mathbf{0}}$ & $\mathbf{P}_{1}$ & Mean & $\mathbf{P}_{\mathbf{0}}$ & $\overline{P_{1}}$ & Mean & $\mathbf{P}_{\mathbf{0}}$ & $\overline{P_{1}}$ & Mean \\
\hline $\mathrm{M}_{0}$ & 2.10 & 2.10 & 2.10 & 0.70 & 0.90 & 0.80 & 0.35 & 0.45 & 0.40 \\
\hline $\mathrm{M}_{1}$ & 2.09 & 2.09 & 2.09 & 0.90 & 0.96 & 0.93 & 0.52 & 0.53 & 0.53 \\
\hline $\mathrm{M}_{2}$ & 2.49 & 2.49 & 2.49 & 1.10 & 1.13 & 1.12 & 0.64 & 0.82 & 0.73 \\
\hline $\mathrm{M}_{3}$ & 3.60 & 3.60 & 3.60 & 3.32 & 3.49 & 3.41 & 0.78 & 0.89 & 0.84 \\
\hline $\mathrm{M}_{4}$ & 4.57 & 4.57 & 4.57 & 3.43 & 3.57 & 3.48 & 1.34 & 1.38 & 1.36 \\
\hline $\mathrm{M}_{5}$ & 7.50 & 7.50 & 7.50 & 4.54 & 4.57 & 4.56 & 2.40 & 2.35 & 2.37 \\
\hline $\mathrm{M}_{6}$ & 10.6 & 10.6 & 10.6 & 6.82 & 7.14 & 6.99 & 4.41 & 4.61 & 4.50 \\
\hline $\mathrm{M}_{7}$ & 4.64 & 4.64 & 4.64 & 3.21 & 3.48 & 3.36 & 1.21 & 1.32 & 1.27 \\
\hline $\mathrm{M}_{8}$ & 7.69 & 7.69 & 7.69 & 4.70 & 4.76 & 4.72 & 2.02 & 2.08 & 2.05 \\
\hline $\mathrm{M}_{9}$ & 10.5 & 10.5 & 10.5 & 6.91 & 6.97 & 6.94 & 4.12 & 4.22 & 4.17 \\
\hline \multirow[t]{2}{*}{ Mean } & 5.58 & 5.57 & & 3.56 & 3.69 & & 1.78 & 1.85 & \\
\hline & SEd & $\begin{array}{l}\text { CD } \\
(p=0.05)\end{array}$ & & SEd & $\begin{array}{l}\text { CD } \\
(p=0.05)\end{array}$ & & SEd & $\begin{array}{l}\text { CD } \\
(p=0.05)\end{array}$ & \\
\hline $\begin{array}{l}\text { Main } \\
\text { plot (M) }\end{array}$ & 0.44 & 0.90 & & 0.31 & 0.65 & & 0.01 & 0.03 & \\
\hline $\begin{array}{l}\text { Subplot } \\
\text { (P) }\end{array}$ & 0.25 & NS & & 0.13 & NS & & 0.03 & NS & \\
\hline $\mathrm{M}$ at $\mathrm{P}$ & 0.73 & NS & & 0.43 & NS & & 0.03 & NS & \\
\hline $\mathrm{P}$ at $\mathrm{M}$ & 0.81 & NS & & 0.42 & NS & & 0.03 & NS & \\
\hline
\end{tabular}


Table.2 Effect of fortified municipal solid waste compost on available heavy metal content (mg $\mathrm{kg}^{-1}$ ) in soil at harvest stage of onion

\begin{tabular}{|c|c|c|c|c|c|c|c|c|c|}
\hline \multirow{2}{*}{$\begin{array}{l}\text { Treatme } \\
\text { nts }\end{array}$} & \multicolumn{3}{|c|}{$\mathbf{P b}$} & \multicolumn{3}{|c|}{$\mathrm{Ni}$} & \multicolumn{3}{|c|}{ Cd } \\
\hline & $\mathbf{P}_{0}$ & $\mathbf{P}_{1}$ & Mean & $\mathbf{P}_{0}$ & $\mathbf{P}_{1}$ & Mean & $\mathbf{P}_{0}$ & $\mathbf{P}_{1}$ & Mean \\
\hline $\mathrm{M}_{0}$ & 0.65 & 0.67 & 0.66 & 0.31 & 0.37 & 0.34 & 0.12 & 0.19 & 0.16 \\
\hline $\mathrm{M}_{1}$ & 0.58 & 0.53 & 0.56 & 0.32 & 0.45 & 0.39 & 0.21 & 0.32 & 0.27 \\
\hline $\mathrm{M}_{2}$ & 0.78 & 0.88 & 0.83 & 0.42 & 0.47 & 0.45 & 0.37 & 0.38 & 0.38 \\
\hline $\mathrm{M}_{3}$ & 0.98 & 1.36 & 1.17 & 1.03 & 1.01 & 1.02 & 0.51 & 0.51 & 0.51 \\
\hline $\mathrm{M}_{4}$ & 1.13 & 2.34 & 1.74 & 1.12 & 1.24 & 1.18 & 0.67 & 0.75 & 0.71 \\
\hline $\mathrm{M}_{5}$ & 4.19 & 4.24 & 4.22 & 1.75 & 2.19 & 1.97 & 0.77 & 0.76 & 0.77 \\
\hline $\mathrm{M}_{6}$ & 6.08 & 6.98 & 6.53 & 3.44 & 3.53 & 3.49 & 2.46 & 2.72 & 2.59 \\
\hline $\mathrm{M}_{7}$ & 1.45 & 1.44 & 1.45 & 0.98 & 1.07 & 1.03 & 0.34 & 0.53 & 0.44 \\
\hline $\mathrm{M}_{8}$ & 3.72 & 3.93 & 3.83 & 1.76 & 2.11 & 1.94 & 0.63 & 0.67 & 0.65 \\
\hline $\mathrm{M}_{9}$ & 5.68 & 5.76 & 5.72 & 3.64 & 3.79 & 3.72 & 2.14 & 2.20 & 2.17 \\
\hline Mean & 2.52 & 2.81 & & 1.48 & 1.62 & & 0.82 & 0.90 & \\
\hline & SEd & $\begin{array}{l}\text { CD } \\
(P=0.05)\end{array}$ & & SEd & $\begin{array}{l}\text { CD } \\
(P=0.05)\end{array}$ & & SEd & $\begin{array}{l}\text { CD } \\
(P=0.05)\end{array}$ & \\
\hline $\begin{array}{l}\text { Main } \\
\text { plot (M) }\end{array}$ & 0.16 & 0.70 & & 0.08 & 0.37 & & 0.12 & 0.53 & \\
\hline $\begin{array}{l}\text { Subplot } \\
\text { (P) }\end{array}$ & 0.33 & NS & & 0.24 & NS & & 0.24 & NS & \\
\hline $\mathrm{M}$ at $\mathrm{P}$ & 0.47 & NS & & 0.33 & NS & & 0.34 & NS & \\
\hline $\mathrm{P}$ at $\mathrm{M}$ & 0.46 & NS & & 0.34 & NS & & 0.34 & NS & \\
\hline
\end{tabular}

Fig.1 Effect of FMSWC on available heavy metal concentration in soil at harvest stage of okra

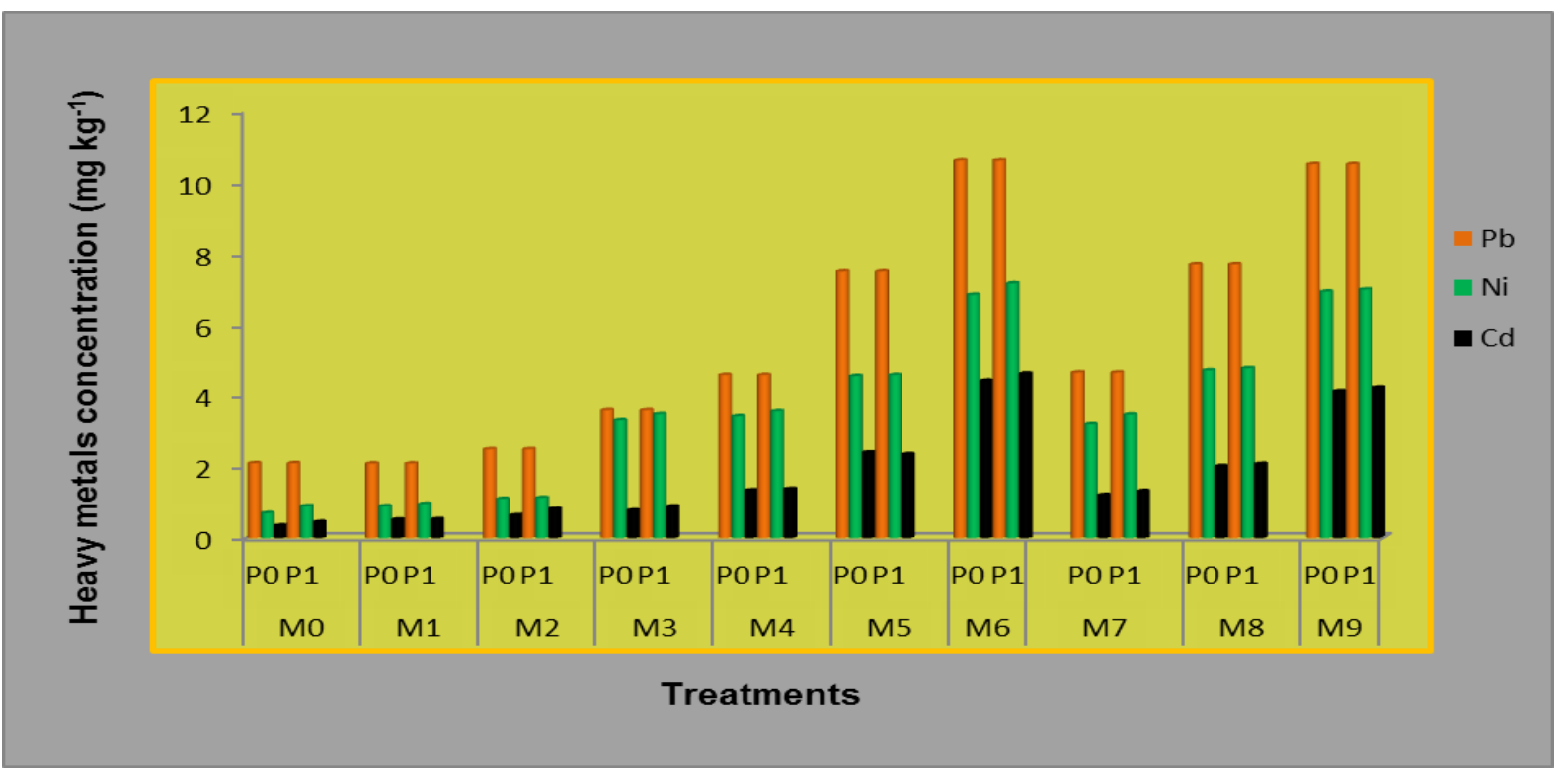


Fig.2 Effect of FMSWC on available heavy metal concentration in soil at harvest stage of onion

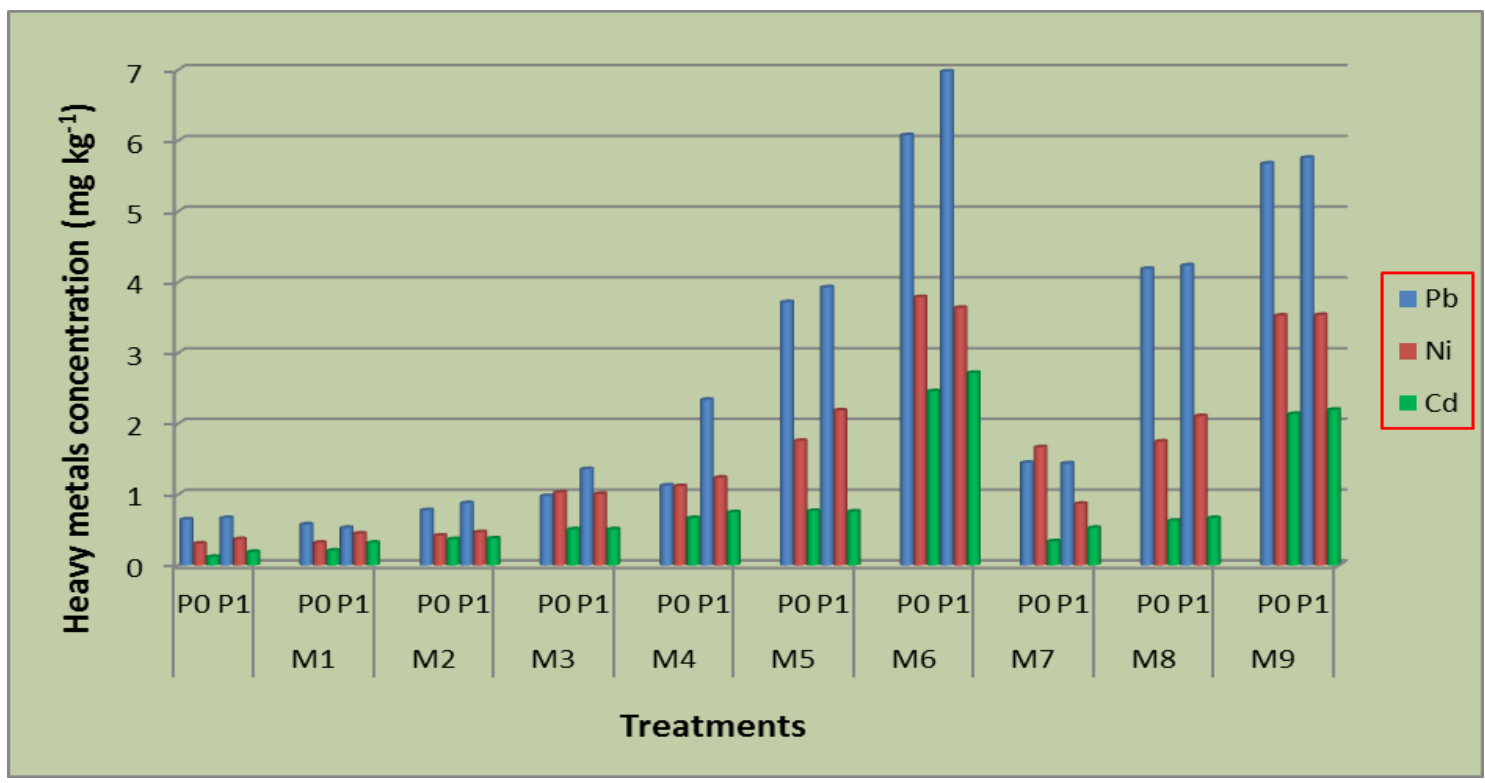

The present results are in line with the findings of Zhang et al., (2006) who observed that application of MSWC at $200 \mathrm{t} \mathrm{ha}^{-1}$ registered highest available cadmium $0.4 \mathrm{mg}$ $\mathrm{kg}^{-1}$ content in soil under barley (Hordeum vulgare L.) - wheat (Triticum aestivum L) canola (Brassica rapa) cropping sequence. Topcuoglu (2016) also reported the effect of long-term municipal solid waste compost applications on heavy metal availability in cucumber as a test crop for three consecutive years and found that application of MSWC at $100 \mathrm{t} \mathrm{ha}^{-1}$ increased $\mathrm{Ni}$ concentration from 0.02 to $40.0 \mathrm{mg} \mathrm{kg}^{-1}$ in soil.

In conclusion, heavy metals concentration in soil was below the permissible limit as prescribed by Indian Standards (2013) and World Health Organization (2007). Hence, MSWC can be effectively utilized as an alternative source of organic manure in the place of FYM along with $100 \%$ recommended dose of fertilizers to obtain maximum fruit yield of okra and bulb yield of onion without environmental pollution.

Abbreviations: MSWC - Municipal Solid Waste Compost, Pb - Lead, Ni- Nickel, CdCadmium and SSP- Single Super Phosphate .

\section{References}

Achiba, W.B., Noureddine Gabteni, Abdelbasset Lakhdar, Gijs Du Laing, Marc Verlooc, Naceur Jedidi, Tahar Gallali. 2009. Effect of 5-year application of municipal solid waste compost on the distribution and mobility of heavy metals in a Tunisian calcareous soil. Ecosys. Environ., 130:156163.

Achiba, W.B., Noureddine Gabteni, Abdelbasset Lakhdar, Gijs Du Laing, Marc Verlooc, Naceur Jedidi, Tahar Gallali. 2009. Effect of 5-year application of municipal solid waste compost on the distribution and mobility of heavy metals in a Tunisian calcareous soil. Ecosys. Environ., 130:156163.

Ayari, F., H. Hamdi, N. Jedidi, N. Gharbi and R. Kossai. 2010. Heavy metal distribution in soil and wheat plants in municipal solid waste compost amended plots. Int. J. Environ. Sci. Technol., 7(3): 465-472.

Businelli D., L. Massaccesi Said, D. Pullicino and G. Gigliotti. 2009. Long-term distribution, mobility and plant availability of compostderived heavy metals in a landfill covering soil. Sci. Total Environ., 407: 1426-1435.

Cherif, H., Fathia Ayari, Hadda Ouzari, Massimo Marzorati, Lorenzo Brusetti, Naceur Jedidi, 
Abdennaceur Hassen, Daniele Daffonchio. 2009. Effect of municipal solid waste compost, farmyard manure and chemical fertilizers on wheat growth, soil composition and soil bacterial characteristics under Tunisian arid climate. Eur. J. Soil Biol.., 45: 138-145.

Convertini, G., D. Ferri, F. Montemurro and M. Maiorana. 2004. Effect of municipal solid waste compost on soils cropped with Tomato and sunflower in rotation with durum wheat. In: $13^{\text {th }}$ Soil Conservation Organization Conference (SCOC), Brisbane, pp: 628.

FAO (Food and Agriculture Organization of united Nation). 2014.

Garcia-Gil, J.C., S.B. Ceppi, M.I. Velasco, A. Polo, N. Senesi. 2004. Long-term effects of amendment with municipal solid waste compost on the elemental and acidic functional group composition and $\mathrm{pH}-$ buffer capacity of soil humic acids. Geoderma, 121: 135-142.

Gharib. Z. 2014. Heavy elements in soils and wastewater influence. J. Sci. Res. Dev., 1(1): 38-44.

Hernando, S., Lobo, M. and Polo, A. (1989) Effect of the application of a municipal refuse compost on the physical and chemical properties of soil. Sci. Total Environ., 81/82: 589-596.

Indian Standards. 2013. http://en/Bureau of Indian Standards.

Kiayee, S.B. 2013. Impact of municipal waste leachate application on soil properties and accumulation of heavy metals in wheat (Triticuma aestivum L). Intl. J. Sci. Res. Environ. Sci., 1(1): 1-6.
Lindsay, W.L. and Norvell. W.A.(1978) Development of DTPA soil test for zinc, iron, manganese and copper. Soil Sci. Soc. Am. J., 42: 421-428.

Lindsay, W.L. and W.A. Norvell. 1978. Development of DTPA soil test for zinc, iron, manganese and copper. Soil Sci. Soc. Am. J., 42: 421-428.

Minghua, Z., Xiumin, A. Rovetta, F. Qichang, H. Vicentini, F. Bingkai, L. Giusti, A and Yi, L. (2009) Municipal solid waste management in Pudong, New Area, China. J. Waste Manage., 29: 1227-1233.

Pigozzo, A.T.G., E. Lenzi, J.L. Junior, C. Scapin and A.C.S. Da Costa. 2006. Transition metal rates in latosol twice treated with sewage sludge. Brazil. Arch. Biol. Technol., 49 (3): 515-526.

Topcuoglu, B. 2005. Effects of repeated applications of sewage sludge and MSW compost on the bioavailability of heavy metals in greenhouse soil. J. Environ. Stud., 14(2): 217-222.

Topcuoglu. B. 2016. Effect of long-term municipal solid waste compost applications on soil metal bioavailability and environmental risks. Intl. J. Adv. Agric. Environ. Eng., 3 (1): 201-207.

WHO (2007) Food additives and contaminants. Food Standards Programme: 1-289.

Zhang, M., D. Heaney, B. Henriquez, E. Solbergan, E. Bittner. 2006. Compost science and utilization, a four-year study on influence of biosolids/municipal solid waste cocompost application in less productive soils in alberta: nutrient dynamics, 14(1): 68-80.

\section{How to cite this article:}

Reddy Kiran Kalyan, V.S., G. Sudha Narayani, A. Vijayaprabhakar and Ch. Bhargavarami Reddy. 2017. Assessment of Heavy Metals on Fortified Municipal Solid Waste Compost Treated Soils (Typic Ustropet) in Okra (Abelmoschus esculentus (L.) Moench) - Onion (Allium cepa L.) Cropping Sequence. Int.J.Curr.Microbiol.App.Sci. 6(2): 637-644.

doi: http://dx.doi.org/10.20546/ijcmas.2017.602.072 